\title{
THE TRADITIONAL CEREMONIES OF TENGGER TRIBE AS A SUSTAINABLE TOURISM OBJECT IN INDONESIA
}

\author{
I Komang ASTINA \\ Universitas Negeri Malang, Faculty of Social Science, Geography Departemen, Indonesia, e-mail: komang.astina.fis@um.ac.id \\ SUMARMI* \\ Universitas Negeri Malang, Faculty of Social Science, Geography Department, Indonesia, e-mail: sumarmi.fis@um.ac.id \\ Maria Yosi FELICIA \\ Universitas Negeri Malang, Faculty of Social Science, Geography Department, Indonesia, e-mail: mariayfelicia2912@gmail.com \\ Elya KURNIAWATI \\ Universitas Negeri Malang, Faculty of Social Science, Sociology Department, Indonesia, e-mail: elya.kurniawati.fis@um.ac.id
}

\begin{abstract}
Citation: Astina, I.H., Sumarmi, Felicia, M.Y., \& Kurniawati, E. (2021). THE TRADITIONAL CEREMONIES OF TENGGER TRIBE AS A SUSTAINABLE TOURISM OBJECT IN INDONESIA. GeoJournal of Tourism and Geosites, 39(4spl), 13711378. https://doi.org/10.30892/gtg.394sp107-780
\end{abstract}

\begin{abstract}
Traditional ceremonies are one of cultural representation that is passed from generations. The public interest in traditional ceremonies was decreased by the time, especially for the younger generation. This study aimed to describe traditional ceremony activities in the Tengger tribe as sustainable tourism objects. The research method is descriptive qualitative using field survey. Data is collected through literature review, observation, and interviews. In-depth interviews were conducted with key informants with extensive knowledge and experience about the research object. The research object is traditional ceremonies such as Kasodo, Karo, and Unan-Unan. Triangulation method was used to test the validity and reliability of research data. The result found that the Yadnya Kasodo is a spiritual ceremony aimed to purify nature and carried out as gratitude to God by offering agricultural goods (sajen) and ongkek. The agricultural goods managed by the community to be used in the ceremony are flowers, fruits, vegetables, and livestock products. This traditional procession is closely related to the Bromo Tengger Semeru National Park spatial layout. Traditional ceremonial activities could become objects of sustainable tourism and are supported by sustainable resources.
\end{abstract}

Key words: Tengger Tribe, Bromo Tengger Semeru National Park, offering, conservation, sustainable tourism

\section{INTRODUCTION}

Human interaction with the environment will form a system that interwoven and influence each other. Changes in one sub-system may impact other sub-systems and likewise (Chandra and Kumar, 2021; Goh, 2021). The environment forms an ecosystem and a spatial system in human interaction (D'Arco et al., 2021). Human activities directly impact nature, while the environmental impact is based on space and time (Marten, 2001; Astina, 2021). Deforestation in mountain areas brings floods to the lowland. No impact happens suddenly but differs in frequency and time, resulting in various other complications (Bintarto and Surastopo, 1979). Human interaction with nature creates a culture (Wood, 2002). Culture results from the works, creativity, taste, actions, and ideas passed down through generations in society (Jovicic, 2014). The elements of culture consist of a religious system, a social system or social organization, a livelihood system, a living equipment system, and technology, art, and language (Koentjaraningrat, 2009). The elements of culture have developed in sync with science and technology, the community, and external influences (He et al., 2021; Pickel-Chevalier et al., 2021).

Traditional ceremonies are one of culture that is passed from generation to generation. The ceremonial activities were periodically involving all members of the community. Traditional ceremonies are a series of actions arranged by customs and legal norms agreed by the community (He et al., 2021). Traditional ceremonies are associated with various events that are considered sacred or significant in a tribe's community (Cathrin, 2017). A tribe is a social group in the cultural system with a specific meaning or position because of heredity, customs, religion, and language (Spillane, 2002). Each tribe has a different culture and customs. It is related to the natural environment, both abiotic and biotic (Plumwood, 2002), while custom is related to community behavior and the sanctions applies (He et al., 2021; Pickel-Chevalier et al., 2021; Soekanto, 2009).

Indonesia has many different cultures and customs in each region. Culture and customs are passed to generations through traditional ceremonies and family education (informal). The ritual ceremony involves all community members, but it is involved the older generation more than the younger generation in ritual activities. Meanwhile, public interest and attention in traditional ceremonies have decreased, particularly among the younger generation (Syarif et al., 2016; Junaidin

\footnotetext{
* Corresponding author
} 
et al., 2020; Mena, 2020). Cultures and customs in some regions began to decrease, even some residents and community members stopped performing certain customs and cultures (Kurniawan et al., 2019).

Tengger tribe is one of the tribes in East Java, Indonesia. This tribe is located in the Tengger Mountains, covering four districts: Probolinggo, Pasuruan, Malang, and Lumajang (showed in Figure 1). This tribe has a distinct culture and customs that were preserved to the present day. Even though the area is a national and international tourist attraction, it is still maintained by the Tengger tribe. Tengger culture and customs remain intact, both sacred and profane, as diversification of tourism objects. This area is designed by the government as Bromo National Park, Tengger Semeru (Sutarto, 2008; Ratman, 2016; Astina, 2021).

Based on the research background above, this study aimed to describe traditional ceremony activities in the Tengger tribe as sustainable tourism objects. Moreover, this study included the process of traditional ceremonial activities and the relationship to the conservation of natural resources and sustainable tourism development.

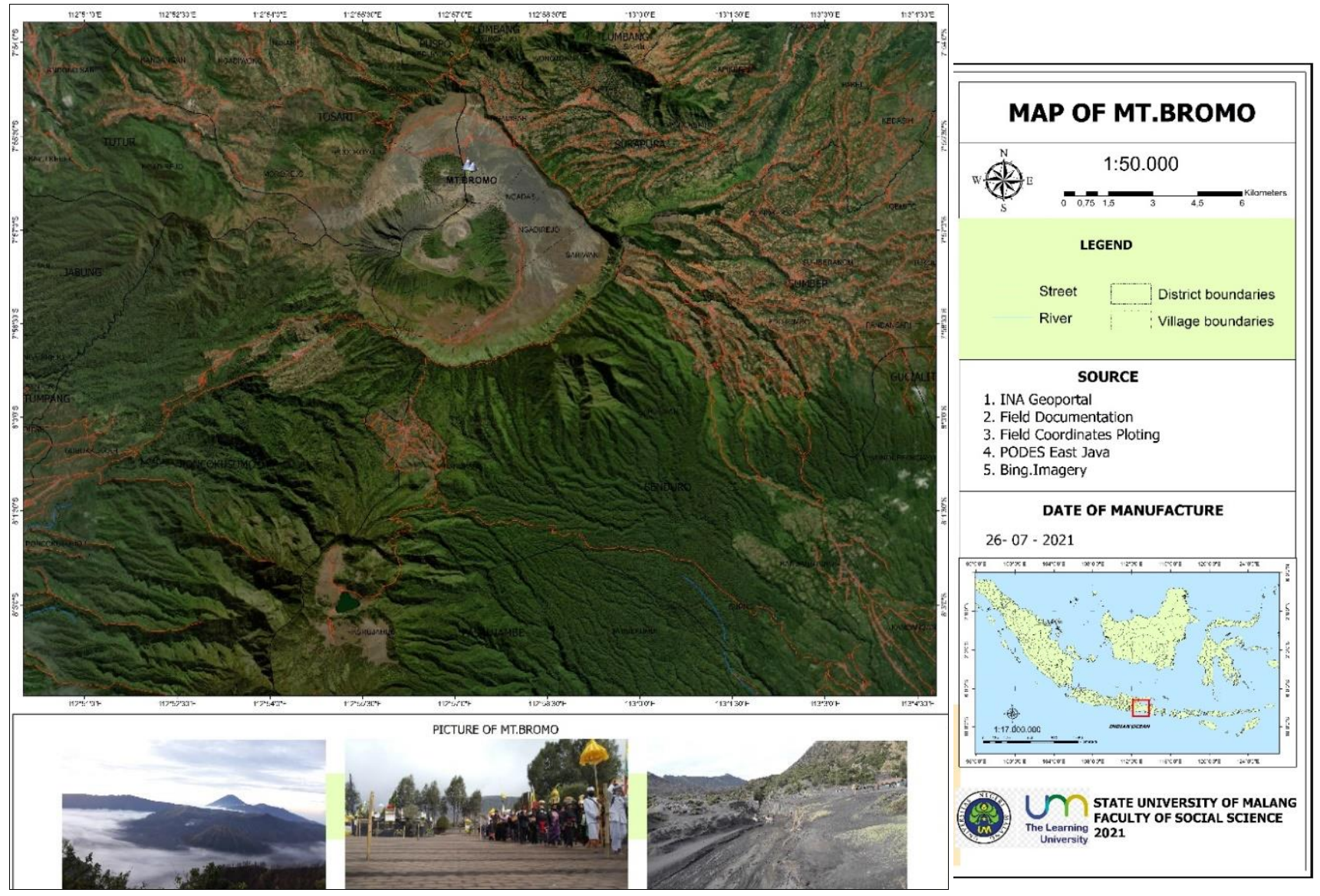

Figure 1. The map and culture of Bromo mountain area

\section{RESEARCH METHODS}

The research studied the Tengger tribe in East Java using qualitative descriptive research. The Tengger tribe lives in the Tengger Mountains or the slopes of Mount Bromo. The Tengger tribe are administratively divided into four regencies: Probolinggo, Pasuruan, Malang, and Lumajang. The research objects are the traditional ceremonies, including Yadnya Kasodo, Karo, and Unan-Unan. Data were collected through literature studies, field observations, and interviews. The data analysis used the triangulation model to study the local wisdom in Tengger Community. Moleong (2016) stated that triangulation is a data validity technique that uses something other than the data to check or partially compare the data. The researchers began with a review of the literature from various sources and then verified through observation and in-depth interviews with traditional leaders, government officials, and community members.

\section{RESULTS AND DISCUSSION}

\section{Tengger Tribe Ceremony}

According to its etymological origin, Tengger means 'to stand upright' or 'to remain motionless.' Meanwhile, the community's beliefs defined tengger as a noble Buddhist, a sign or characteristic that gives a special nature to something. Tengger also can mean 'noble character traits.' The Tengger tribe lives a simple and peaceful life, enjoys collaboration, has a high tolerance for others, and is a hard worker as they usually work from morning to evening in the fields. The tribe lives in a mountainous area, specifically on the slopes of the Tengger and Semeru mountains. The Tengger tribe has 5 'ma' principles to avoid: maling (thief), main (gambling), madat (drugs), minum (drunk), madon (cheating), and 5 'wa' principles to follow: waras (healthy), wareg (proper eating), wastra (proper clothing), wasis 
(proper knowledge), wisma (decent living). Culture is a comprehensive system of human ideas and actions resulting from human interactions with the environment in a particular area. Culture takes the form of ideas or standards, activities, objects, and people. The culture functions to express a sense of community, stimulate changes and fulfill the community's needs through a way of living (He et al., 2021). Custom has several meanings based on the Indonesian dictionary (Ministry of National Education, 1988). A custom is a repeated pattern that has developed into a habit. Another definition of custom is a system of values, norms, and rules related to each other. Customs are permanent and conduct from generation to generation, as an inheritance integrated with community behavior patterns.

Traditional ceremonies are a series of actions or activities with specific rules according to religion or customs in an area. Traditional ceremonies are closely related to religious rituals or rites (Atmadja, 2020; Sumarmi et al., 2019). Rituals are symbolic of religion, or rituals are religion and actions (Ghazali, 2011). The traditional ceremony is determined by four factors: the location, the time, the objects and equipment used, and the people involved in the implementation. The traditional ceremonies are located in a sacred place or sacred place believed by the community. The ceremonies were happed in a specific year, month, and day based on the traditional calendar, agreed by the traditional elders and the community. The ceremonial objects and equipment are considered sacred as well based on community beliefs. The view in Bromo montain that used for ceremonies is shown in Figure 2 and Figure 3.
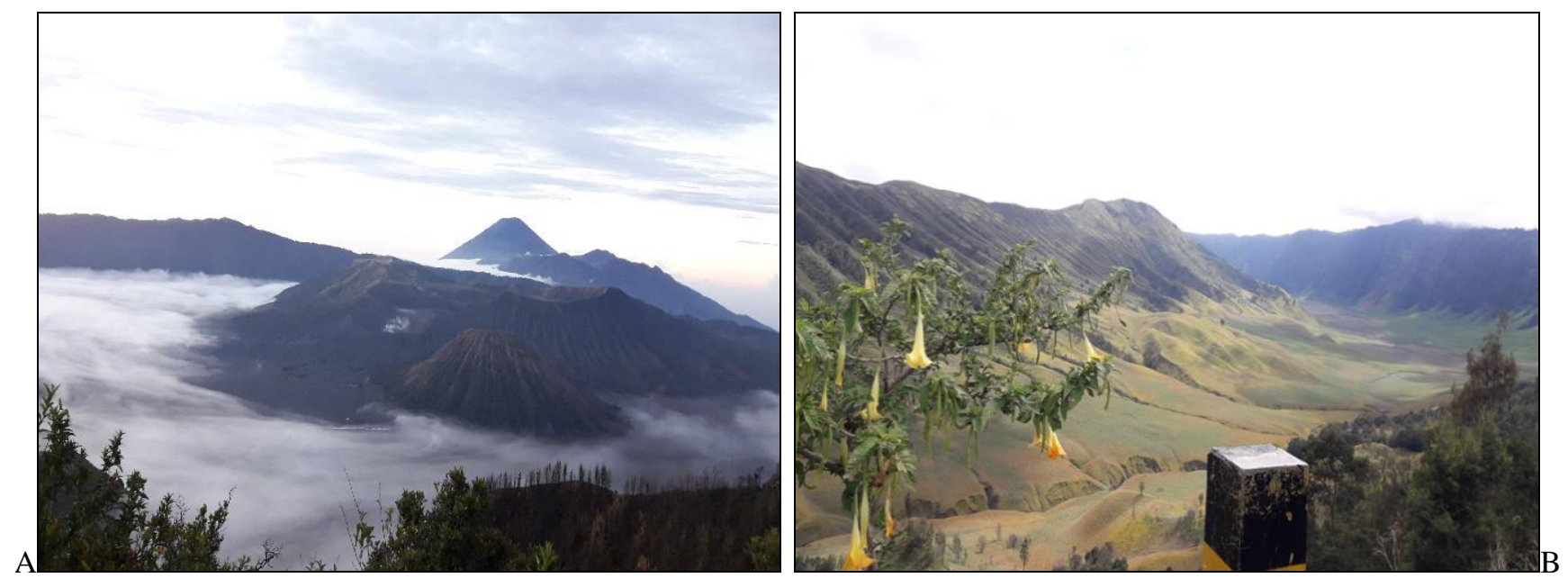

Figure 2. (A) The view of Bromo mountain and Sea of Sand covered in sunrise's fog

(B) The flowers that used for ceremonies equipment by Tengger tribe
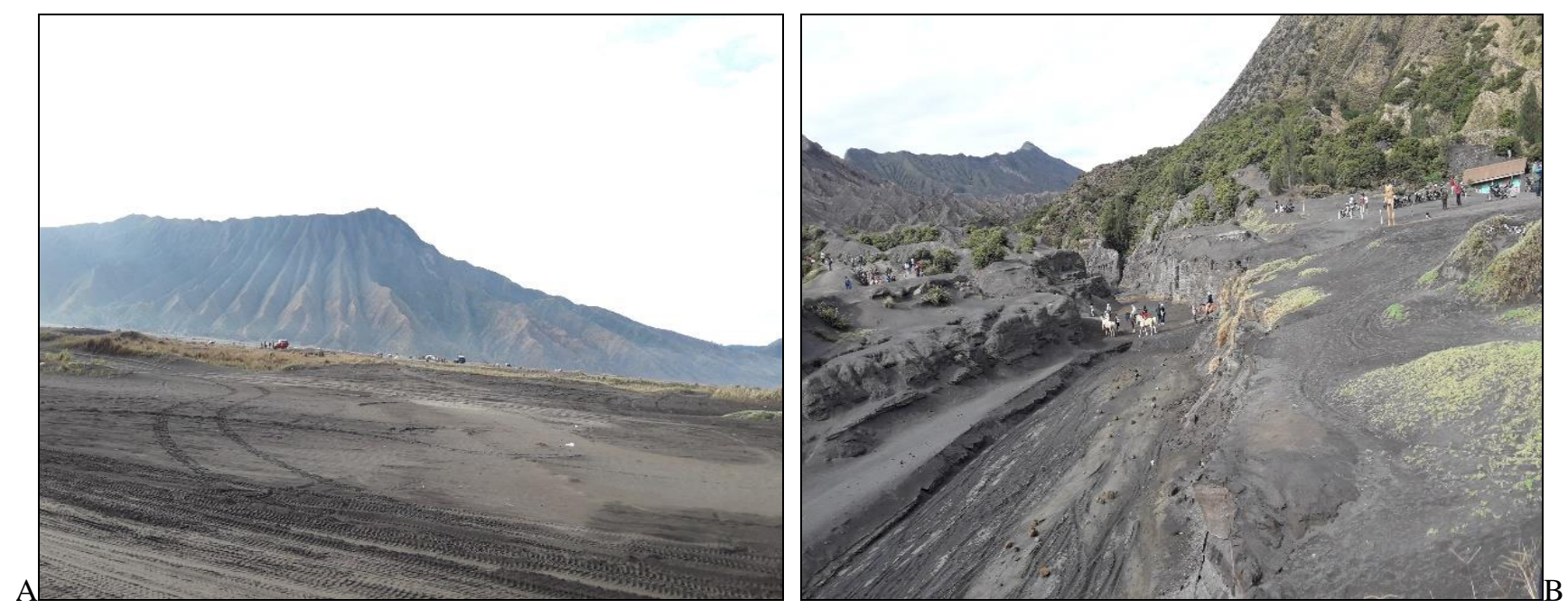

Figure 3. (A) The Sea of Sand's parking area (B) Walking route and horse trail to Bromo mountain peak

The Tengger tribe believed that the universe and all of its components, including humans, were created. Human birth and life are representations of the goodness of God, the gods, Pitra, and Rsi (Satriawan, 2019; Mertayasa, 2019). Therefore, humans should "pay the debt of goodness" (Rna, Sanskrit) to God, ancestors, and the sages to create balance, harmony led to happiness and peace. The human debt is owed to God as the creator (Brahma), the preserver (Vishnu), and the destroyer (Ciwa) called Lord Rna. Pitra Rna (pitr = father and mother) is a debt to the ancestors, while Rsi Rna is a debt to those who have given knowledge and guidance towards goodness and peace. The thing that should be done to "pay" the debt is through a sacred offering or sacrifice called Yadnya (Panca Yadnya). The implementation of Yadnya in the Tengger community is carried out in various traditional ceremonies. Three traditional ceremonies, including Yadnya Kasodo, Karo, and Unan-Unan, are explained in the following section. 


\section{Yadnya Kasodo}

The Yadnya Kasodo ceremony is a sacred offering ceremony (Yadnya) addressed to God (Hyang Widhi), the gods, and the ancestors of the Tengger people. The ceremony is related to the legend of Roro Anteng and Joko Seger, which later became the name of the Tengger tribe. The legend tells of the sacrifice of their beloved last son (25) (Savitri, 2010). This ceremony is a spiritual honor and purification of nature (Bhuwana Agung), including mountains, by worshiping God (Hyang Widhi), the gods, and ancestors by offering Yadnya. It is aimed to get a beautiful and fertile nature that gives prosperity and prosperity (Chandra and Kumar, 2021). The Yadnya Kasodo ceremony was attended by the Tengger tribe in Probolinggo district, Pasuruan, Malang, and Lumajang.

Based on the historical background, procedures, equipment, and the implementation of this ceremony is a combination of local beliefs and Hinduism. However, this ceremony was followed by the Tengger tribe as a whole, including the non-Hindu member. The day before the Kasodo Yadnya is held, the community performed a self-cleaning ceremony and ceremonial equipment (Melasti) at the water source on Mount Widodaren. The Kasodo ceremonies began from the shaman Pandita's pavilion house to carry out the preparation ceremony for offerings and ongkek.

Furthermore, the parade group traveled together to the Poten noble temple. This temple is located in the Sea of Sand at the slope of Mount Bromo (Figure 1). This temple is the meeting center (Pancer) from the four scattered regions (papat sedulur). A prayer ceremony is held in the central part of the Poten temple mandala. A trip to Mount Bromo is made at midnight to offer banten and ongkek in the mountain's crater. While the Yadnya Kasodo ceremony was held, a Pandita/traditional shaman called Diksa Widhi was also tested and graduated.

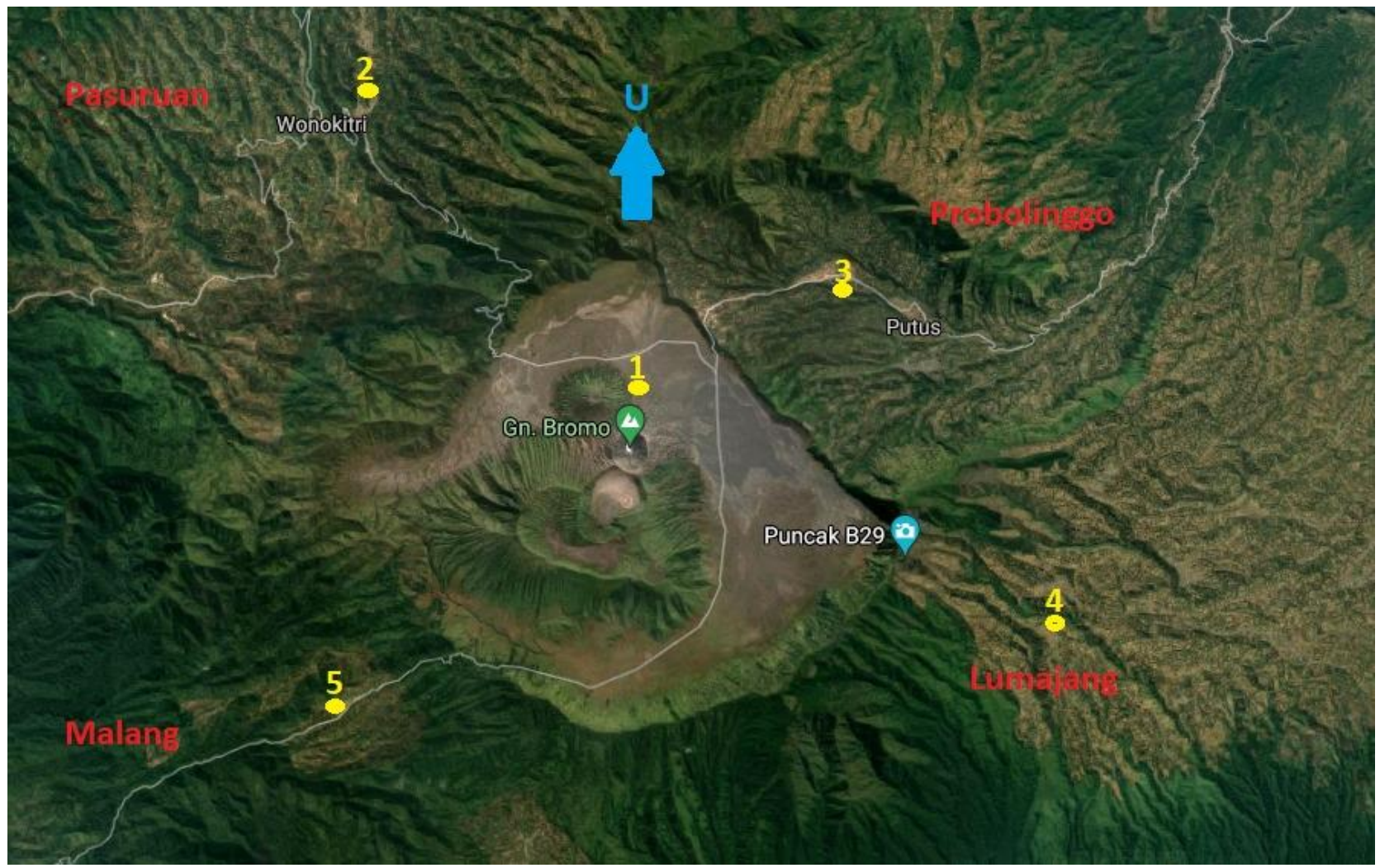

Figure 4. The map of Tengger and Pura caldera

The Luhur Poten temple (see 1) were used as pancer or center. The Papat Sedulur center with the main rooms is Dhankahyangan Agung Kerta Jaya Temple, Tosari, Pasuruan (2), Brahma Karana temple, Sukapura, Probolinggo (3), Tri Kahyangan Jagad Temple, Senduro, Lumajang (4) and Sapto Argo temple, Ngadas, Malang (5). All traditional ceremonies are related to the five locations. The Bromo crater is an offering place made for God or Hong Pukulun or Hyang Widhi, the gods and the ancestors of Tengger tribe. The crater is called 'Port' to invoke the harmony of nature as a location for offering (by anchoring or throwing). The offering includes 'Banten' consisting of a series of flowers and leaves, and 'Ongkek' is the offering bowl for fruits and cakes, each totaling 30. Tengger tribe offered chicken and goat for a special purpose. All the equipment was provided by Tengger tribe. The ceremony is held annually by the Tengger Tribe. The ceremony is held between the 14th, 15th, and 16th day of month Kasada, according to the Tengger calendar during the full moon. The offerings are agriculture and livestock products. It is arranged into banten and Ongket (consists of 30 types of fruit and 30 types of cakes) as a symbol of creators, preservers, and destroyers (Interviews with youth leaders and EK educators from the Tengger tribe). The map of Tengger area and Pura caldera is shown in the following Figure 4.

\section{Yadnya Karo Ceremony}

Yadnya Karo ceremony is the most extended series of traditional ceremonies carried out by the Tengger tribe. 
According to the Tengger Calendar, the ceremony is held on the sixteenth day of the full moon in Karo month. Karo refers to the origins of human existence, and the descent of the spirit returns to Hyang Widhiwasa. This yadnya is also an expression of gratitude to God, Hong Pukulun Hyang Widhi who has created the pair Joko Seger and Roro Anteng as ancestors of the Tengger tribe (Setiawan and Ratnasari, 2015). This ceremony is performed as Rna by performing Yadnya Karo, Yadnya Dewa (God and the Gods), and Yadnya Pitra (ancestor). The Yadnya Karo ceremony lasts for two weeks, with various series of ceremonies. The ceremony starts from each household with a 'Ping Pitu' ceremony by inviting the Spirit or Atman of their ancestors. This ceremony of Sesanding or Sesanti can also be held at the local village hall.

Furthermore, the 'Prepekan' ceremony is an offering (ngaturi) of the 'Danyang' (the guardian spirits of the village), punden, and water sources. This place is sacred by the Tengger tribe. Further, the community visited the village leader's house to gather and eat together (Kauman) accompanied by traditional entertainment (Tayub). Then residents visited the village leader's house with small tumpeng (rice). The pandita shaman leads the worship procession and the offering of the cone with various complementary offerings (makeup). After that, all residents fought over the tumpeng, to be enjoyed and some to take home. It is represented as a symbol of prosperity, hope, and prayer for a successful harvest.
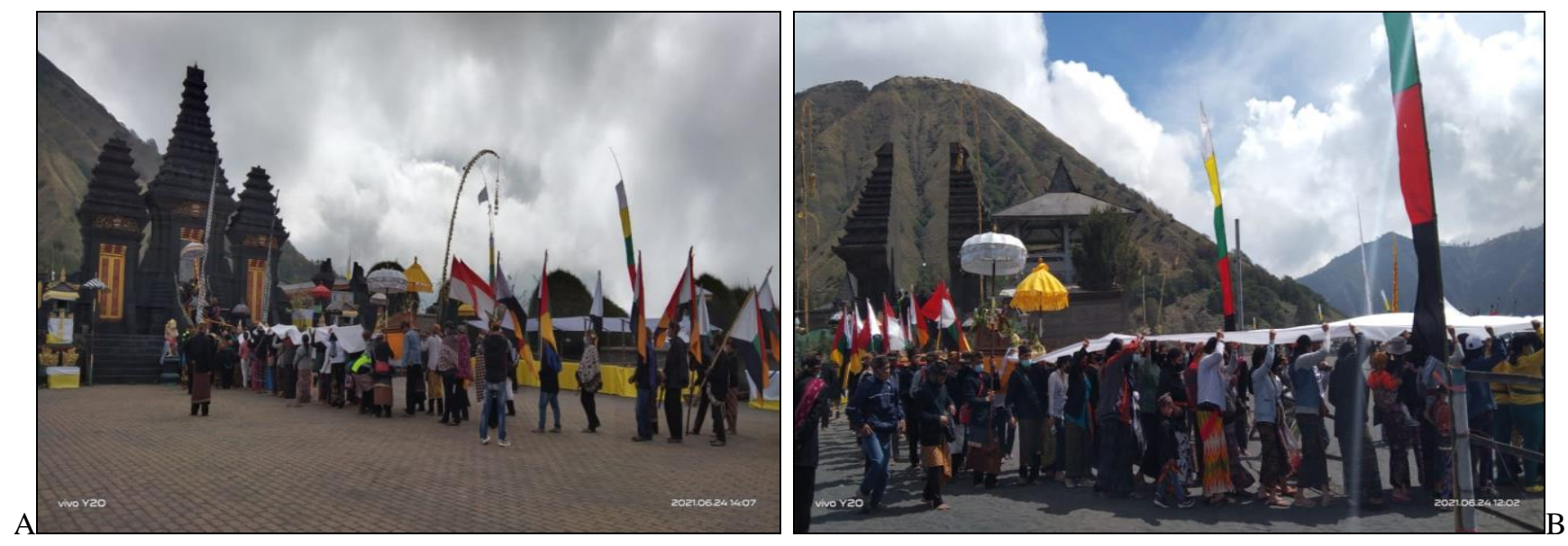

Figure 5. The preparation of Kasodo ceremony in Luhur Poten temple

Figure 6. The departure of Kasodo ceremony from Luhur Poten temple

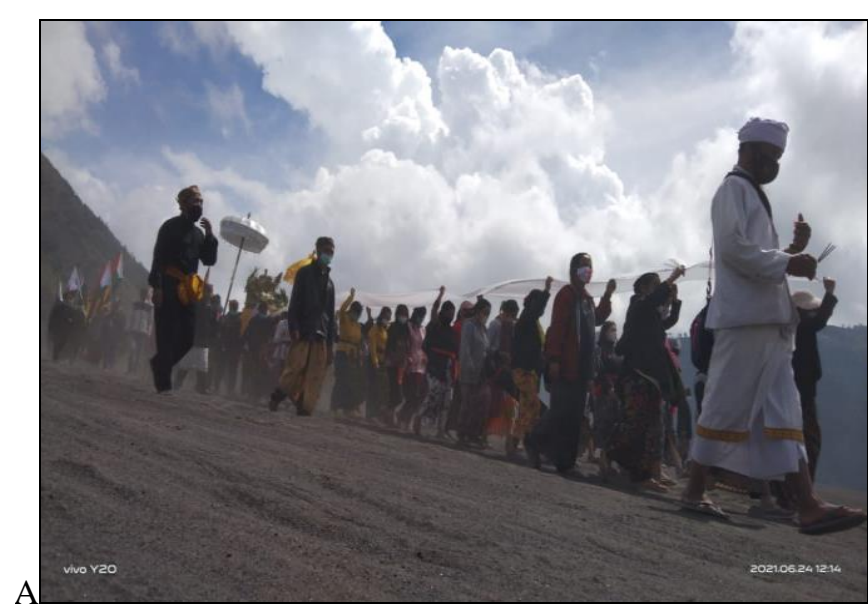

Figure 7. The parade of Kasodo ceremony in Luhur Poten temple

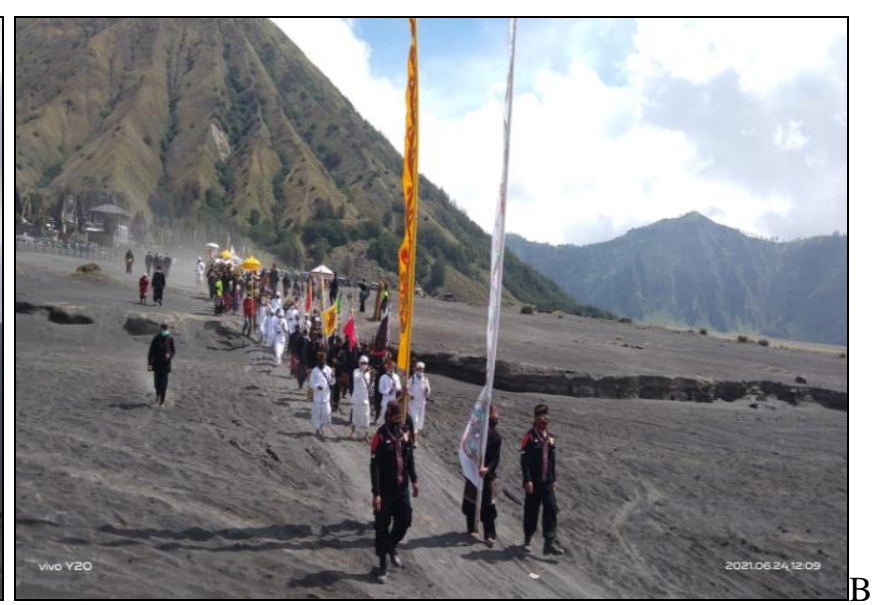

Figure 8. The parade group goes to Bromo mountain peak to put sajen (offering) vol 1-2022-Jordan-04.10.---30.11.----

A sacred dance, the Sodoran dance, is performed during the Yadnya Karo traditional ceremony. This dance described the history of human creation on earth in pairs of men and women (Purusha and Perdana). The dance began with a parade of village brides (male symbols) carrying heirlooms such as kitchen utensils and decorated bamboo sticks to the village hall for village brides (female symbols). Village brides from these two villages are symbols of the meeting of two people (Karo means two, and Karo also means the second month in the Tengger Calendar system).

This event started with a man dancing with buffalo horns. It described a mighty man looking for a mate or partner. Then the dancers take turns in pairs carrying bamboo sticks with decorations. It described men as guardians and will fight for the integrity and peace of the household (Ratih and Juwariah, 2020). Male Tengger residents are the only ones that witness this dance, while female residents with food in a basket wait outside. The eating session was held after the dance. The ceremony process is shown in Figure 5 to 8.

The next ceremony is 'nundung arwah,' a ceremony to invite the spirits of the ancestors to return to their nature. Furthermore, the Pandita (village shaman) and several ceremony officers traveled around the village to visit the community with Prapen (Fire stove) and holy water (Tirta) (Savitri, 2010). Prapen with a fragrant smell (incense) as an intermediary symbol to God, as a destroyer of bad things (mala), while water symbolizes the grace and cleansing of nature and humans. On the final day, Sadranan ceremony was held on the tomb to pray for ancestors and family spirits. 


\section{Unan-Unan}

This ceremony was aimed to purify the earth or the village of all dangers and disturbances. It is also aimed to clean or purify the imperfect spirits. This ceremony is held every five years with a big ceremony carried out in Punden village. The facilities used in this ceremony are "Dandanan" offerings in large quantities and offerings of buffalo heads (maheso). The ceremony leader is a Pandito (customary shaman) to perform purification and offerings with Tengger traditional mantras.

Unan-unan is based on the Tengger word 'nguna,' which means to attract or complete the lost moon to return. The traditional calendar divides each month into 30 days and another into 29 days, resulting in a difference of five or six days each year. The difference in days is included in the 11th month to complete this deficiency (Dhesta or Jhiesta Month). Therefore, once every five years, the Tengger tribe conducted the Unan-Unan ceremony (interview with traditional leaders). The Unan-unan ceremony is used to keep the village clean and free of all spirit disturbances. It is also used to purify spirits that remain impure in the world after physical death to escape hell and return to nirvana. The following are the tools required for the Unang-unang ceremony: (a) new 'klasa' (bamboo mats), (b) plentiful of rice, (c) 100 pieces 'takir' (banana leaf bowl), (d) betel, (e) 100 pieces of satay skewer made from sacrifice meat, (f) 100 pieces of concoction, and (g) buffalo's head. The community kills a buffalo the day before the Unan-Unan ceremony. The meat is needed to make 100 pieces of skewers. The buffalo's head, skin, and four legs are left. The ceremony's equipment includes offerings of flower arrangements, leaves, and fruit, as well as 100 tumpeng and 100 leaf-wrapped snacks.

According to the Tengger tribe belief, the buffalo was the first animal that appeared on earth. This animal is also a symbol of the prosperity of society. They believe that buffalo is a technology created by the ancestors as a balance to natural energy. The parts of the buffalo used for offerings include the skin, head, tail, and a small portion of the buffalo meat for the skewer. The rest of the meat is given to the community.

The buffalo heads are paraded through the village, accompanied by a mantra from Pandita to the Main Hall, as a symbol of rural areas being cleaned up and a ceremony being conducted smoothly. The Unan-unan ceremony is used to enact protection from God, Hyang Widhi, Hong Pokulun (another name for God), and ancestors to neutralize negative forces in nature, not just for the Tengger tribe but for all humankind (Interviews with young community leaders EK).

\section{Traditional Ceremonies and Sustainable Tourism}

The Tengger tribe lives in the Bromo Tengger Semeru National Park area. It is a volcanic complex with large calderas in the four-stage evolution of a stratovolcano. The calderas are Nongkojajar Caldera, Ngadisari Caldera, Tengger Caldera and Sand Sea Caldera (Sutarto, 2008). This mountain complex has natural geological resources related to volcanoes, water resources, geomorphology, ecology, culture, and tourism (Chandra and Kumar, 2021; D’Arco et al., 2021). Bromo Tengger Semeru mountain area is one of ten tourism strategy areas developed by the Indonesian government. The development includes attractions, public infrastructure and facilities, tourism facilities, and community empowerment (Nugroho, 2011; Ratman, 2016). Therefore, a spatial arrangement of objects and tourism supporters is required for the destination's development as a sustainable tourism destination (Chandra and Kumar, 2021; Goh, 2021). The Tengger tribe has a traditional spatial layout, namely Tri Mandala consist of main, middle, and nista (Suryadarma, 1993). The Main mandala (Utama Mandala) is a sacred space that must be respected, protected, and conserved. The Madya mandala is a transition place from sacred and profane places for limited tourism activities, while Nista mandala is a profane space (Astina, 2021).

The Tengger tribe lives in this National Park area is committed to preserving the natural environment as a livelihood. They maintain the area's sanctity based on the belief that the mountain is the home of the gods (Div) or holy rays from God, Hitun or Hyang Widi, and the ancestors. Mountains, hills, other elevated areas, and forests are the top ecosystems that protect the space ecosystem or the lower part (Odum and Barret, 2017). In general, this space is physically and spiritually higher (Suryadarma, 1993; Astina, 2001; Sukari, 2004; Andik, 2003).

Pedanangan, Punden, and water sources, including the ecosystem with existing plants and animals (Sukojo, 2003; Kurniawati et al., 2020), are sacred rituals associated with traditional ceremonies. All traditional Tengger ceremonies occur continuously according to a schedule based on their traditional calendar. The ceremony will continue to take place as long as the traditional society exists. Agricultural products such as flowers, fruits, and vegetables, including natural flora such as Edelweiss flowers, are the materials used in all traditional ceremonies (Wood, 2002; Sumarmi, 2018). The ceremony requires livestock products such as poultry (chickens and ducks) and goats. The ceremony occurs at a specified time on annual basis, so it is necessary to meet the ceremony's requirements.

The Tengger tribe's ceremony has not decreased in popularity due to modernization but has actually increased enthusiasm among the younger generation. Performing a traditional ceremony as a Yadnya (sacred offering) is not a waste of time or money but a spiritual requirement obtained from the natural environment. The Tengger tribe's traditional ceremony is closely connected to the Bromo, Tengger, and Semeru area's attractions. It provides additional evidence for a sustainable tourism process. The Tengger tribe's cultural resources play a critical role in the development of tourism in Mount Bromo. The carrying capacity of tourism includes two categories: physical and non-physical categories (Chandra and Kumar, 2021; D’Arco et al., 2021). Physical categories include the natural environment, village spatial planning, architecture, fauna (horses used for tourist transportation), and flora (used as ceremonial instruments), while non-physical categories include customs, ceremonies, and the arts (Sumarmi, 2018).

Conservation of the previously mentioned resources is highly dependent on the Tengger community and the traditional leaders' role (shamans). The Tengger tribe's strength in honoring noble intrinsic values as ancestor heritage must be preserved. It is demonstrated by the Tengger tribe's commitment to performing rituals based on the beliefs that have passed down through generations, such as the Kasodo, Karo, and Unan-unan ceremonies. The strong paternalistic 
culture also contributes to the preservation of the Tengger tribe's cultural resources. Based on the result by (Sutiarso, 2018) showed that the development and change of Tengger tribe are closely connected to the role of influential people, such as traditional leaders (shamans) and village government leaders. All kinds of village ritual activities are determined, led and regulated by traditional leaders (shamans). Meanwhile, no resident dared to change, substitute, or violate the shaman's ruling. Due to the charismatic influence of the shaman on village leadership, Tengger's sociocultural values to new generations have been successful in many cases. It has a significant impact on the sustainability of Mount Bromo's tourism industry, which is closely related to the culture (Jovicic, 2014).

Some myths still dominate the Tengger tribe's life and contribute to tourism in Bromo Tengger Semeru National Park in nature conservation. One of the myths that have remained is the belief in the sacredness of Mount Bromo and surrounding areas. The Kasodo ceremony is a form of respect for the sacred myth of Mount Bromo. The Kasodo ceremony believes in the spiritual power that humans must submit to Sang Hyang Widhi and work diligently for their lives while prioritizing the preservation of nature (the existence of ecological wisdom) to avoid losing the support of nature acquires autonomous power. Sustainability development aimed to develop tourism area that care to natural resource and human needs (Pickel-Chevalier et al., 2021; Zhang and Chan, 2020).

\section{CONCLUSION}

The Tengger tribe's traditional ceremony involves a sacred offering called Yadnya. Yadnya is carried out obligations or Rna to God, Hitun or Hyang Widhi, and the ancestors. The ceremony is determined based on the traditional calendar, repeated every year for Yadnya Kasodo and Karo, and five years for Unan-Unan. This ceremony is a part of the Bromo Tengger tourist attraction. The Trimandala spatial planning concept supports the sustainable development of tourism objects. It is related to the sacred space that must be protected, the madya space, and the profane space.

The traditional ceremony is performed according to a spatial layout that spiritually purifies the Bromo Tengger Semeru National Park area. The offering goods in the ceremony are agricultural products, such as flowers, fruits, vegetables, and livestock products. The offering represents gratitude to God Hong Pukulun, Hyang Widhi, and the ancestors for the gift of beautiful and fertile nature. The traditional ceremony of the Tengger Tribe has been proven to have preserved the Bromo Tengger Semeru National Park's natural condition and has been developed into an international tourist attraction. Therefore, this ceremony must be supported by government regulations.

\section{Acknowledgement}

This research is supported by the Faculty of Social Sciences, Universitas Negeri Malang and the Tengger Tribe in Bromo Tengger Semeru National Park. This research has no conflict of interest to any party or institution.

\section{REFERENCES}

Andik, P. (2003). Agama Tradisional; Potret Kearifan Hidup Masyarakat Samin dan Tengger [Traditional Religion; Portrait of the Wisdom of Samin and Tengger Community Life], Yogyakarta, LKiS.

Astina, I.K. (2001). Pembangunan dan Tata Ruang Tradisional [Traditional Building and Layout]. Paper Presented at the Pertemuan Ilmiah Tahunan, Indonesian Geographers Association (PIT IGI, 23 Oktober 2001), Universitas Negeri Malang, Unpublished.

Astina, I.K., Suyadi, S., Dhananjaya, A. (2021). Brata Penyepian dalam Konteks Lingkungan dan Covid 19 [Brata Penyepian in the Context of the Environment and Covid 19]. Papers at the 2021 Hindu Spiritual Seminar, LP3 UM., Unpublished.

Astina, I.K. (2021). The spatial layout of the Tengger community for structuring the tourism objects and social studies materials. Paper Presented at the International Conference on Social Studies and Educations Issues (ICOSSEI), 2021, Social Studies Program, Faculty of Social Science, Universitas Negeri Malang, Unpublished.

Atmadja (2020). Melalui Catur Brata Penyepian Kita Tingkatkan Satyagraha Untuk Mewujudkan Satyam, Siwam dan Sundaram [Through Catur Brata Penyepian We Improve Satyagraha To Realize Satyam, Siwam and Sundaram]. Nyepi celebration seminar paper 2020. LP3 UM, Unpublished.

Bintarto \& Surastopo, H. (1997). Metode Analisis Geografi [Geographical Analysis Method]. Jakarta, LP3ES.

Chandra, P., \& Kumar, J. (2021). Strategies for developing sustainable tourism business in the Indian Himalayan Region: Insights from Uttarakhand, the Northern Himalayan State of India. Journal of Destination Marketing \& Management, $19,100546$. https://doi.org/10.1016/j.jdmm.2020.100546

Cathrin, S. (2017). Tinjauan Filsafat Kebudayaan Terhadap Upacara Bersih Desa di Desa Tawon Kecamatan Pasreman, Ngawi Jawa Timur [Cultural Philosophy Overview of the Village Clean Ceremony in Tawun Village, Pasreman District, Ngawi, East Java]. Jurnal Filsafat, 27(1). https://doi.org/10.22146/jf.22841

D’Arco, M., Lo Presti, L., Marino, V., \& Maggiore, G. (2021). Is sustainable tourism a goal that came true? The Italian experience of the Cilento and Vallo di Diano National Park. Land Use Policy, 101, 105198. https://doi.org/10.1016/j.landusepol.2020.105198

Departemen Pendidikan Nasional. (1988). Kamus Besar Bahasa Indonesia [Indonesia Dictionary]. Jakarta, Balai Pustaka.

Ghazali, A.M. (2011). Antropologi Agama [Religious Anthropology]. Bandung, Alfabeta.

Goh, H.C. (2021). Strategies for post-Covid-19 prospects of Sabah's tourist market - Reactions to shocks caused by pandemic or reflection for sustainable tourism? Research in Globalization, 3, 100056. https://doi.org/10.1016/j.resglo.2021.100056

He, J., Huang, Z., Mishra, A.R., \& Alrasheedi, M. (2021). Developing a new framework for conceptualizing the emerging sustainable community-based tourism using an extended interval-valued Pythagorean fuzzy SWARA-MULTIMOORA. Technological Forecasting and Social Change, 171, 120955. https://doi.org/10.1016/j.techfore.2021.120955

Junaidin, Utaya, S., Astina. I.K., \& Susilo, S. (2019). Land resource management of Sambori indigenous community area viewed from Ethnoecological aspects. Eco. Env. \& Cons. 25 (4), 131-138, EM International ISSN 0971-765X.

Jovicic, D.Z. (2014). Key issues in the implementation of sustainable tourism. Current Issues in Tourism, 17(4), $297-302$. https://doi.org/10.1080/13683500.2013.797386 
Koentjaraningrat (2009). Pengantar Ilmu Antropologi [Introduction to Anthropology]. Jakarta, Rineka Cipta.

Kurniawati, E., Sumarmi \& Aliman, M. (2020). Participation of Green Environmental Group and Ulur-Ulur Local Wisdom on Buret Lake Ecotourism Management in Karst Area of Tulungagung, Indonesia. GeoJournal of Tourism and Geosites, 30(2spl), 889-895. https://doi.org/10.30892/gtg.302spl15-519

Kurniawan, M., Faisal, E.E., \& Kurnisar (2019). Faktor Faktor yang Menyebabkan Perubahan Adat Istiadat Ngocek Bawang di Kelurahan Indralaya Mulya, Ogan Ilir [Factors Causing Changes in the Customs of Ngocek Bawang in Indralaya Mulya Village, Ogan Ilir]. Jurnal Bhineka Tunggal Ika, 6(1). https://doi.org/10.36706/jbti.v6i1.7928

Marten, G. (2001). Human Ecology, Basic Concepts for Sustainable Development. London: Earthscan Publications.

Mena, E.N., Budijanto, Astina, I.K., \& Susilo, S. (2020). Pelestarian Lingkungan, Dalam Adat Penti Masyarakat Manggarai [Environmental Preservation, In the Penti Custom of the Manggarai Community]. Malang: Ediide Infografika.

Mertayasa, I.K. (2019). Yadnya Sebagai Penguatan Pendidikan Karakter [Yadnya Strengthening Character Education]. Tampung Penyang. 17(2). https://doi.org/10.33363/tampung-penyang.v17i01.431

Moleong, L.J. (2016). Metode Penelitian Kualitatif [Qualitative research methods]. Bandung, PT Remaja Rosdakarya.

Nugroho, I. (2011). Ekowisata dan Pembangunan Berkelanjutan [Ecotourism and Sustainable Development]. Yogyakarta: Pustaka Pelajar.

Odum, E.P., \& Barret, G.W. (2017). Fundamental of Ecology (fifth edition). Australia, Thompson, Brooks/Cole Cengage Learning.

Ratman, D.R. (2016). Strategi dan Program Kerja Destinasi Pariwisata [Tourism Destination Work Strategy and Program]. Deputy for Destination Development and Tourism Industry. Indonesia Ministry of Tourism.

Ratih, E., \& Juwariah (2020). Konstruksi Sosial Upacara Adat Karo Suku Tengger di Desa Tosari [Social Construction of the Karo Traditional Ceremony of the Tengger Tribe in Tosari Village]. Jurnal Analisis Sosiologi, 9(2). https://doi.org/10.20961/jas.v9i2.42103

Pickel-Chevalier, S., Bendesa, I.K.G., \& Putra, I.N.D (2021). The integrated touristic villages: An Indonesian model of sustainable tourism? Tourism Geographies, 23(3), 623-647. https://doi.org/10.1080/14616688.2019.1600006

Plumwood, V. (2002). Environmental Culture, The Ecological Crisis of Reason. London, Routledge. https://books.google.co.id/books? id $=4$ sQvKiZd4i4C

Setiawan, H., \& Ratnasari, M. (2015). Wawasan Budaya Nusantara Suku Tengger [Cultural Insights of the Tengger Tribe Archipelago]. Surakarta: Institut Seni Indonesia.

Sutarto, A. (2008). Kamus Budaya Dan Religi Tengger (Dictionary of Tengger Culture and Religion). Jember: Lembaga Penelitian Universitas Jember.

Syarif, E., Fatchan, A., Sumarmi \& Astina, I.K. (2016). Hutan dan Masyarakat Adat Ammatoa, Tinjauan Dalam Perspektif Pasang ri Kajang [The Ammatoa Forest and Indigenous Peoples, An Overview in the Perspective of Kajang Pasang]. Malang: Aditya Media Malang, ISBN 978-602-323-079-2.

Soekanto, S. (2009). Sosiologi Suatu Pengantar (An Introduction to Sociology). Jakarta, Rajawali Pers.

Sukari. (2004). Kearifan Lokal di Lingkungan Masyarakat Tengger, Kabupaten Pasuruan, Propinsi Jawa Timur [Local Wisdom in the Tengger Community, Pasuruan Regency, East Java Province]. Yogyakarta: Kementerian Kebudayaan dan Pariwisata.

Sukojo, B.M. (2003). Pemetaan Ekosistem di Wilayah Gunung Bromo dengan Teknologi Penginderaan Jauh (Mapping Ecosystems in the Mount Bromo Region Using Remote Sensing Technology). Makara Teknologi, 7(2), 63-72. https://doi.org/10.7454/mst.v7i2.166

Sumarmi. (2018). The Local Genius of Tengger People in Conserving Forest and Increasing Economic Benefits Using Agroforestry System. IOP Conference Series: Earth and Environmental Science, 145(1), 012135. https://doi.org/10.1088/1755-1315/145/1/012135

Sumarmi., Bachri, S., Tanjung, A., \& Mutia, T. (2019). A Study on the Local Wisdom of the Bali Aga Community Metruna Nyoman in The Indigenous Forest as an Effort to Build Character of Caring for the Environment. Ecology, Environment, \& Conservation. 25 (4), 1638-1643, EM International ISSN 0971-765X.

Spillane, J.J. (2002). Pariwisata Indonesia - Siasat Ekonomi dan Rekayasa Kebudayaan [Indonesian Tourism-Economic Strategy and Cultural Engineering]. Penerbit Kanisius dan Lembaga Studi Realino. Yogyakarta.

Suryadarma (1993). The Role of Yadnya in The Conservation of Plant Diversity on The Yard Spatial Pattern in Bali. Yogyakarta: FMIPA, IKIP Yogyakarta.

Sutiarso, M.A. (2018). Pengembangan Pariwisata yang Berkelanjutan Melalui Ekowisata [Sustainable Tourism Development through Ecotourism]. https://doi.org/10.31219/osf.io/q43ny

Zhang, S., \& Chan, E.S.W. (2020). A modernism-based interpretation of sustainable tourism. International Journal of Tourism Research, 22(2), 223-237. https://doi.org/10.1002/jtr.2330

Savitri, A. (2010). Sejarah, Agama dan Tradisi Suku Tengger Gunung Bromo [History, Religion and Traditions of the Tengger Tribe of Mount Bromo]. https://adoc.pub/queue/sejarah-agama-dan-tradisi-suku-tengger-gunung-bromo.html

Wood, M.E. (2002). Ecotourism. Principles, Practices \& Policies for Sustainability, UNEP.

*** Satriawan, I.K. (2019). Tri Rna. Accesed 22 July 2021. https://forumstudimajapahit.com/tri-rna/

Article history: $\quad$ Received: 23.06.2021 Revised: 22.11.2021 Accepted: 07.12.2021 Available online: 31.12 .2021 